\title{
Change and Challenge: Ontario's Collaborative Baccalaureate Nursing Programs
}

Dale Kirby

Memorial University of Newfoundland

\begin{abstract}
There is no formal mandate for or tradition of inter-sectoral collaboration between community colleges and universities in Ontario. Following a regulatory change introduced by the College of Nurses of Ontario in 1998, all Registered Nurse educational preparation was restructured to the baccalaureate degree level through province-wide adoption of a college-university collaborative nursing program model. Despite complex sectoral differences in organizational culture, mandates, and governance structures, this program model was promoted by nursing educators and policy-makers as an innovative approach to utilizing the post-secondary system's existing nursing education infrastructure and resources. This paper provides an overview of the introduction of Ontario's collaborative baccalaureate nursing programs and discusses some of challenges associated with implementing and maintaining such programs.
\end{abstract}

\section{RÉSUMÉ}

En Ontario, il n'y a pas de mandat officiel ni de tradition de collaboration intersectorielle entre les collèges communautaires et les universités. À la suite d'une modification réglementaire apportée par l'Ordre des infirmières et infırmiers de l'Ontario en 1998, toute la formation pédagogique de niveau baccalauréat du personnel infirmier a été re- 
structurée par l'adoption à la grandeur de la province d'un modèle de programme de formation en sciences infirmières offert conjointement par les collèges et les universités. En dépit de différences complexes entre ces deux secteurs aux plans de la culture organisationnelle, des mandats et des structures de gouvernance, les enseignants en soins infirmiers et les décideurs ont fait la promotion de ce modèle de programme en tant qu'approche novatrice pour utiliser l'infrastructure et les ressources de formation en sciences infirmières déjà en place dans le réseau postsecondaire. Cet article offre un aperçu de l'introduction des programmes ontariens de baccalauréat conjoint en sciences infirmières et examine quelques-uns des obstacles associés à la mise en œuvre et au maintien de ces programmes.

The post-secondary education system in Ontario, like the post-secondary systems in most other Canadian provinces, is characterized by the existence of discrete university and community college sectors supplemented by institutions offering specialized programs (i.e., agricultural or fine arts programs). Unlike the dominant community college model in the United States with its focus on university transfer, Ontario's colleges of applied arts and technology (CAATs) were originally established to provide career-oriented occupational, vocational, and adult basic education for individuals not destined for university study (Dennison, 1995; Jones, 2004). Unlike governments in provinces such as Alberta, British Columbia, and Quebec, the Government of Ontario has no formally mandated role in facilitating college to university transfer. Throughout the history of their co-existence, Ontario's colleges and universities have persisted within a binary policy structure governed by separate and distinct regulatory regimes. Generally speaking, there has been little inter-sectoral (i.e., college-university) co-ordination in the system, with few students moving from the CAAT programs on to university-level studies (Jones, 1997; Skolnik, 1995; Skolnik \& Jones, 1993; Stokes, 1989). This paper reviews the introduction of Ontario's collaborative baccalaureate nursing programs, their supporting policies, and many of the challenges that have been encountered to date. Many of my observations are informed by my experiences in working with the nursing education community as a public servant in Ontario's Ministry of Training, Colleges and Universities from 2000 to 2006.

\section{College-University Collaboration in Ontario}

From the early 1990s onward, there have been increasing calls for a greater level of co-ordination and closer linkages between Ontario's colleges and universities. The Ontario government has often been a major proponent of this position. The Vision 2000 task force's review of the Ontario CAAT system recommended the establishment of "a coordinating body" whose role would be to facilitate transfer and articulation arrangements between the province's colleges 
and universities (Ontario, 1990). Since the release of Vision 2000's final report, a number of subsequent government-sponsored committees, commissions and task forces, appointed to examine post-secondary education in Ontario, have endorsed the furtherance of inter-sectoral co-ordination and recommended a variety of approaches for improving student pathways between the college and university sectors (Ontario 1993; 1996; 2001; 2005).

In response to such proposals, the Ontario Ministry of Training, Colleges and Universities created the College-University Consortium Council (CUCC) in 1996. The CUCC's formally stated mission is

to facilitate, promote and coordinate joint education and training ventures that will: aid the transfer of students from sector to sector; facilitate the creation of joint programs between colleges and universities; and, further the development of a more seamless continuum of post-secondary education in Ontario. (College-University Consortium Council, 2006, ${ }^{1}$ )

In addition to its occasional promotional activities, the CUCC's primary focus has been the production of an on-line Ontario college-university transfer guide. The CUCC transfer guide is a compilation of existing college-university collaborative programs, articulation agreements and credit transfer arrangements.

In another move toward improved collaboration, in 1999 the Ministry of Education and Training, the Association of Colleges of Applied Arts and Technology of Ontario (ACAATO) and the Council of Ontario Universities (COU) jointly produced the Ontario College-University Degree Completion Accord (often referred to as the "Port Hope Accord"). The Port Hope Accord set out a framework for voluntary degree completion arrangements between universities and colleges and established guidelines for articulating 2-year and 3-year college diploma programs to university degree programs (e.g., a three-year diploma plus 1.4 to 1.8 additional years of university study for a four-year baccalaureate degree) (College-University Consortium Council, 1999). According to Michael Skolnik (personal communication, August 28, 2006), colleges considered the arrangements agreed upon in the accord to be the maximum requirements for degree completion. Still, unlike an integrated and regulated policy framework with incentives to encourage co-ordination, the inter-sectoral arrangement outlined in the Port Hope Accord is voluntary and non-binding on institutions represented by the signatories. The majority of college-university articulation arrangements in Ontario continue to be bilateral - between one sending institution and one receiving institution.

In recent years, the boundaries separating Ontario's universities and community colleges have become somewhat less discrete. For most of their history, provincial legislation has essentially enabled Ontario universities to hold a near public monopoly on the granting of degrees. In the past, provincial legislation has prohibited the granting of degrees by non-university post-secondary institutions (Skolnik, 1987). This changed with the assent of the Post-Secondary Education Choice and Excellence Act in 2000. The new Act cleared the way for 
the possible establishment of private universities and for the first time permitted Ontario colleges to offer baccalaureate degrees in applied areas of study. In accordance with the legislation, use of the term "university" and the authority to grant degrees are subject to Ministerial discretion and considered on a caseby-case basis. The Minister is informed in part by the advice of an appointed body, the Post-secondary Education Quality Assessment Board (PEQAB) (Jones, 2004). Ministerial consent for degree-granting is conditionally extended for a designated time period and subject to a formal PEQAB follow-up evaluation.

It was in this environment of shifting boundaries and increasing dialogue on articulation and inter-sectoral integration that the nursing profession, with the co-operation of the Ontario government, decided that the entry-to-practice education requirement to become a registered nurse (RN) in Ontario would become a baccalaureate degree from an Ontario university (or equivalent). Because three-year college diploma programs traditionally accounted for approximately $70 \%$ of RN education activity in the province, the change to an all-baccalaureate model presented a significant challenge for the nursing community, the government and, perhaps most especially, the colleges and universities providing students with nursing education.

\section{Nursing Education Reform}

Over a period of about 50 years beginning in the 1930s, a string of nursing reviews and reports called for fundamental reforms in Canadian nursing education. Time and again it was recommended that significant changes to nursing education curricula be undertaken, and that the practice of using nursing students as a source of cheap labour be abolished in favour of better utilization of the growing supply of nursing school graduates. It was not until the 1970s, however, that nursing education began to shift from the hospital training programs that were largely based on the apprenticeship training model to postsecondary programs at Ontario's relatively new colleges of applied arts and technology. By the early 1980s, the transformation was mostly complete, with the majority of nursing students then receiving their education in programs delivered at a college or university (Kerr \& MacPhail, 1996). Graduates from either a college diploma program or a university degree program were equally eligible to write the national registration exams required to become a registered nurse.

The early 1980s saw a growing consensus within the nursing profession that a baccalaureate degree should be the only accepted educational requirement for the entry-to-practice of new RNs. In 1982, the Board of Directors of the Canadian Nurses Association (CNA) unanimously endorsed the notion of a baccalaureate degree as the minimum entry-to-practice requirement. In a paper entitled Entry to the Practice of Nursing, the CNA also encouraged each provincial nursing association to, by the year 2000, endorse the baccalaureate standard for all new nurses seeking registration (Canadian Nurses Association, 1982). At this time, the Registered Nurses Association of Ontario (RNAO) was one of the leading proponents of "degree-as-entry" for the nursing profession in Ontario. 
The rationale for the CNA and RNAO position stemmed from the belief that in order to meet the increasingly complex system-wide demands of technological advances, a culturally diverse patient base, and increasingly acute patient care needs, the future delivery of nursing care would require more sophisticated knowledge and skills than were present in existing training programs. A baccalaureate-level education was considered to be key to the provision of optimal nursing care in this changing and challenging health care context. It was also believed that a science-based baccalaureate nursing program would help in recruiting students who would view nursing as a valued profession and a highly desirable career destination.

In another key development, the position of the CNA and the RNAO was endorsed by Ontario's college and university nurse educators in a statement released in 1995. This statement, entitled Education of the Nurse of the Future, recommended a collaborative baccalaureate program model which would be positioned to capitalize "on the combined resources of college and university programs and hospital and community clinical agencies - building on the strengths of all partners" (Provincial Steering Committee on the Future of Nursing Education, 1995, p. 1).

In December 1998 the College of Nurses of Ontario (CNO), which has responsibility for the regulation of the nursing profession, approved new entrylevel practice competencies for RNs. Reflecting the wishes of most of those involved in nursing and nursing education, the CNO decided that all new registrants would be required to be educated at the baccalaureate degree level as of January 1, 2005. By that time, five other Canadian provinces (the four Atlantic provinces and Manitoba) had already adopted the baccalaureate level RN education requirement.

In March of the following year, the Ontario Minister of Health effectively reversed the government's long-standing position opposing the baccalaureate entry requirement and announced the provincial government's acceptance of all recommendations contained in the Nursing Task Force report Good Nursing, Good Health: An Investment for the 21st Century. This task force had been established by government in 1998 to identify and suggest strategies to ensure the maintenance of quality nursing services within the changing health care system. The task force report endorsed the CNO's call for a baccalaureate requirement for entry-to-practice for all new RNs beginning in the year 2005. The report also recommended the implementation of collaborative college-university baccalaureate programs as the most efficient way, during a period of fiscal retrenchment and restraint, to maximize the existing nursing education infrastructure, resources and expertise. The report further suggested that government take the measures necessary to "remove barriers and add financial incentives for partnering between community colleges and universities, to provide relevant, accessible and portable education programs" (Ontario, 1999, p. 8).

At the time of the release of the Nursing Task Force report, there were 22 colleges in 29 locations offering diploma-level RN preparation and 10 universi- 
ties offering degree-level nursing education. There was only one collaborative nursing degree program in operation, involving Georgian College in Barrie and Seneca College and York University in Toronto. During the previous decade, a number of colleges and universities had attempted to develop collaborative nursing programs but these had ultimately not been successful. The institutions participating in these initiatives cited that they were unable overcome difficulties they encountered due mainly to differences in institutional cultures, governance structures, administrative processes and procedures and provincial funding policies that did not reflect the true cost of mounting collaborative programs.

\section{Collaborative Baccalaureate Policy Implementation}

In reaction to the CNO's regulatory change, the Ministry of Health and the Ministry of Education and Training in April 1999 jointly established an advisory committee that was primarily composed of college and university presidents and deans and directors of nursing. The mandate of this Nursing Education Implementation Committee (NEIC) was to advise stakeholders (i.e., government, colleges, universities and the nursing profession in general) on strategies for utilizing resources in existing college-based 3-year nursing diploma programs in the creation of 4-year college-university collaborative degree programs.

The NEIC's final report provided a comprehensive overview of the barriers to establishing the proposed collaborative programs. As had been suggested previously, large-scale college-university collaboration faced significant challenges due to sectoral differences in key areas such as institutional culture, admission requirements, tuition fee policies, registration processes, human resource requirements, governance and funding mechanisms. The NEIC provided specific recommendations for addressing each of these barriers. The report recommendations included expanded operating funding and transitional funding grants from government, and called for commitment, goodwill and flexibility on the part of colleges and universities developing collaborative programs (Nursing Education Implementation Committee, 1999).

In the spring of 2000, the Ontario government announced the funding and policy framework under which the collaborative nursing programs would be developed and supported (Ontario, 2000). Prior to this announcement many colleges and universities had already begun to focus in earnest on the cultivation and planning of collaborative partnerships for a preferred program start date of September 2001. Since the new registration regulations made eligibility for professional registration contingent on candidates having received a baccalaureate degree from an accredited university program, government advised colleges that wished to continue to prepare nursing graduates to write the national RN registration exam that they would now be required to find a university partner with which to collaborate. Universities were informed that stand-alone nursing baccalaureate programs (i.e., programs delivered without collaboration with a college partner) would no longer receive additional 
operating funding for enrolment growth. Universities wishing to grow undergraduate nursing enrolment would have no alternative but to seek out a college partner.

In accordance with the advice of the NEIC, government also announced that it would provide university-level funding for all enrolments in collaborative nursing programs. Similarly, tuition fees for the programs could, regardless of delivery site, be charged at the university level. As an incentive, government also announced that it would provide $\$ 20$ million in transitional funding over three years to assist institutions with start-up and development expenses. Some of the significant additional cost pressures previously identified included the costs of renovations, equipment, furniture, computer hardware and software, materials and supplies, library resource upgrading, curriculum development and integration, clinical education development, and faculty development.

To enable the initial cohort of students to graduate from the four-year baccalaureate programs by 2005 , most of the college-university collaborative baccalaureate programs began accepting students in September 2001. At the outset, there were 14 collaborative nursing programs involving 20 colleges and 12 universities. One additional program partnership delayed start-up until September 2002. Some of the partnerships were formed between a university and a single college while others involved a university and a number of colleges. Two of the programs offered French-language baccalaureate nursing education. Reflecting the observed tradition of CAATs partnering with out-of-province universities (Skolnik \& Jones, 1993), Humber College in Toronto formed a partnership with the University of New Brunswick which was already delivering a degree completion program at Humber. Table 1 includes the comprehensive list of the college and university partnerships offering collaborative programs in September 2002.

The collaborative programs were for the most part designed following one of three delivery models - articulated, integrated or hybrid. In the articulated programs, the first part of the program, usually the first two years, are delivered by the college partner with the remaining years delivered by the university. In the case of the integrated program model, both the college and university partners are from the beginning involved in each year of the program, with different instructional activities provided by each institution. Students in integrated collaborative programs enter either a university or college site and take the same courses with common exams. Students and faculty may move back and forth between the institutions or stay at the same site through all four years of the program. For programs following a hybrid model, students complete their initial two years at either a college or a university, followed by two years of study at a university. In most cases, regardless of the partnership structure, students at both the university and college sites have access to shared resources, such as the libraries, at each partner institution. 
Table 1: Collaborative Baccalaureate Nursing Partnerships Operating in Ontario in September 2002

\begin{tabular}{|c|c|c|}
\hline University & College(s) & Program Model \\
\hline Brock University & Loyalist College & Hybrid \\
\hline Lakehead University & Confederation College & Integrated \\
\hline Laurentian University & $\begin{array}{l}\text { Cambrian College, Northern College, Sault } \\
\text { College }\end{array}$ & Integrated \\
\hline Laurentian University $^{1}$ & Collège Boréal & Integrated \\
\hline McMaster University & Conestoga College, Mohawk College & Integrated \\
\hline Nipissing University & Canadore College & Integrated \\
\hline Queen's University ${ }^{2}$ & St. Lawrence College & Articulated \\
\hline Ryerson University & Centennial College, George Brown College & Hybrid \\
\hline Trent University & Sir Sanford Fleming College & Integrated \\
\hline $\begin{array}{l}\text { University of New } \\
\text { Brunswick }\end{array}$ & Humber College & Integrated \\
\hline University of Ottawa & Algonquin College & Integrated \\
\hline University of Ottawa ${ }^{1}$ & La Cité collégiale & Integrated \\
\hline $\begin{array}{l}\text { University of Western } \\
\text { Ontario }\end{array}$ & Fanshawe College & Hybrid \\
\hline University of Windsor & Lambton College, St. Clair College & Hybrid \\
\hline York University ${ }^{3}$ & $\begin{array}{l}\text { Durham College, Georgian College, Seneca } \\
\text { College }\end{array}$ & Articulated \\
\hline $\begin{array}{ll}1 & \text { French-language progra } \\
2 & \text { This partnership took its } \\
3 & \text { Durham College entered } \\
\text { Technology in } 2003 .\end{array}$ & $\begin{array}{l}\text { nal intake of students in September } 2004 \text {. } \\
\text { to a new partnership with the University of Onta }\end{array}$ & o Institute of \\
\hline
\end{tabular}

\section{Challenges of Collaboration}

Since its introduction, Ontario's collaborative baccalaureate in nursing has had some success. For example, in light of concerns of an impending shortage of nurses, colleges and universities have responded by raising overall nursing enrolment in the province to levels last achieved in the mid-1990s (Ontario, 2006). This has been accomplished in spite of the significant restructuring of the $\mathrm{RN}$ entry-to-practice educational requirements. Additionally, these collaborative programs have also set the stage for greater inter-sectoral co-operation in other areas of health sciences education such as clinical education and inter-professional health education. However, as might be anticipated, a number of significant and familiar challenges to effective and balanced collaboration remain. 
The issues and challenges associated with offering college-university collaborative programs have been well-documented. These are often related to complex sectoral differences in organizational culture, mandates, and governance structures (Molzahan \& Purkis, 1994; Nursing Education Implementation Committee, 1999; Skolnik, 1996). These differences are to a large extent grounded in the differing historical traditions and academic aims of universities and community colleges. Ontario universities, like all modern Canadian universities, trace their heritage to the medieval European studia generalia of Bologna, Paris, Oxford, and Cambridge. Universities are oriented toward the dual aims of teaching and research as initiated by the first research universities of $18^{\text {th }}$ century Scotland and the Humboldtian universities of early $19^{\text {th }}$ century Germany. In contrast to universities, Ontario's community colleges are a much more recent invention, being established through legislation in the mid-1960s. Since their founding, the primary function of Ontario's CAATs has been to provide occupationally-oriented technical and vocational training along with adult general education and upgrading programs (Dennison \& Gallagher, 1986; Jones 1997).

The issues and challenges outlined below can contribute to disagreement and tension amongst college and university partners involved in the joint delivery of Ontario's nursing baccalaureate programs. Many of these were issues were identified before the systemic implementation of Ontario's collaborative nursing programs and have been influenced by government and institutional policy decisions made in the process of implementing and maintaining the programs.

\section{Program Accreditation}

In September 2000, the College of Nurses of Ontario decided that the accreditation process of the Canadian Association of Schools of Nursing (CASN) would serve as the provincial regulatory approval mechanism for Ontario's collaborative nursing programs. Under this national accreditation program, new nursing program partnerships may opt to first undergo a review to attain pre-accreditation candidacy. As of January 2005, all of Ontario's collaborative nursing programs achieved CASN candidacy (or accreditation). Now that the programs have produced their first graduates, all programs without full CASN accreditation are required to undergo a comprehensive CASN accreditation review. Whereas the approval for pre-accreditation candidacy requires that programs meet a minimum standard, CASN accreditation requires that baccalaureate nursing programs meet peer-established national standards of excellence. One of the key assessment criteria in the accreditation process is nursing scholarship, which CASN has defined as follows:

Scholarship in nursing encompasses a full range of intellectual and creative activities that may include the generation, validation, synthesis, and/or application of knowledge to advance the teaching, research and practice of nursing. It is associated with achievement of excel- 
lence, rigorous inquiry, reflective thought, expert knowledge, openness to criticism, peer review, and new ways of viewing phenomena of concern to nursing. It includes inquiry that builds a scientific body of nursing knowledge (scholarship of discovery), inquiry that supports the pedagogy of the discipline and the transfer of knowledge to learners (scholarship of teaching), generation and use of specialized nursing knowledge outside the work setting (scholarship of service), the advancement of clinical knowledge through expert practice (scholarship of application), and the development of new insights as a result of interdisciplinary work (scholarship of integration) (CASN, 2004, p. 3).

Unlike the promotion and tenure system in universities, compensation and promotion arrangements for college faculty (i.e., collective agreements) do not generally require or reward scholarly activities. Since the CAATs are primarily concerned with teaching rather than scholarly research activities, this aspect of CASN accreditation has placed pressure on some CAAT faculty to meet somewhat unfamiliar expectations.

\section{Effective Governance}

Skolnik and Jones's (1993) study of inter-sectoral co-ordination found articulation between college and university sectors to be most effective and successful in provinces where mechanisms for co-ordination were mandated and the associated policy objectives well-established. Universities in Ontario have traditionally enjoyed a level of autonomy greater than that of most publicly funded post-secondary institutions in North America and arguably, internationally. The CAATs on the other hand are far less autonomous and often more likely to be subject to government intervention (Dennison, 1995). As there is no formal policy framework for college-university collaboration in Ontario and because the province's post-secondary institutions do not have a history of collaboration, there is a concern that the successful implementation of intersectoral collaborative programs may be compromised by irreconcilable issues of a cultural and/or jurisdictional nature.

Previous experience has shown that for college-university collaboration to be successful, the decision-making processes governing institutional co-operation must be explicit, effectively communicated and mutually understood (Barton, 2005; Gaber, 2003; Molzahan \& Purkis, 2004; Skolnik, 1995; Skolnik \& Jones, 1993). Institutions involved in collaborative arrangements should develop appropriate accountability processes while at the same time taking measures that mutually respect the internal autonomy of partner institutions (Barton, 2005; Molzahan \& Purkis, 2004; Skolnik \& Jones, 1993). Additionally, governance of inter-sectoral collaborations should suitably reflect respect for the role of all partners. This is especially important in the case of the collaborative nursing degree program since universities are considerably empowered by their exclusive authority to grant the baccalaureate degree in nursing. In the absence of an 
effective governance structure, CAATs may be relegated to a secondary role in delivering portions of the collaborative nursing degree program. This could contribute to difficult working relationships for all parties involved in collaboration, particularly amongst college and university faculty members. Further, this may have a particularly disempowering impact on college faculty and staff.

\section{Student Admissions}

Closely associated with governance is the issue of student admissions. In reflection of their differing historic traditions and mandates, Ontario colleges and universities differ in their approach to student admission requirements. For the most part, the colleges are oriented toward providing a high level of access to programs for their local community with particular attention to local labour market needs. In contrast, the universities have traditionally exercised a high degree of selectivity in admissions, admitting only those applicants who have successfully completed high school and attained a specified level of academic achievement (Dennison, 1995; Jones, 1997). In some cases, the discourse of selectivity in university admissions processes is perceived, perhaps misperceived, by the college community as a form of elitism that signifies some level of university resistance to inter-sectoral collaboration (Molzahan \& Purkis, 2004; Skolnik \& Jones, 1993).

When Ontario's collaborative nursing programs were introduced en masse, government chose not to mandate a single application and admission process in an effort to preserve the autonomy of colleges and universities in their respective admissions decisions. For some collaborative partnerships, this has resulted in a cumbersome, dual admissions process. Applicants to the collaborative baccalaureate can be made through the universities' application system, the Ontario Universities' Application Centre (OUAC), or the colleges' application system, the Ontario College Application Services (OCAS). As a result, in a number of cases there are parallel admission processes, one university and one college, for entry to a single collaborative nursing program. In addition to causing challenges and confusion for program applicants, this dual admission process represents an additional cost of collaboration. Where the dual process exists, applicants can actually pay an application fee twice for the same program in the event that they apply to a program through both application centres.

\section{Interpersonal Relationships}

In an analysis of the history of co-ordination and collaboration between British Columbia's post-secondary institutions, Gaber (2003) emphasized the importance of positive inter-personal relationships in forming and maintaining successful inter-institutional collaborations. In fact, most of the research focussing on the area of inter-institutional collaboration has highlighted the importance of goodwill, trust, and positive attitudes toward collaboration if institutions are to foster stable working relationships (Barton, 2005; Molzahan 
\& Purkis, 2004; Renaud, 2000; Richardson, 1993; Skolnik, 1995; Skolnik \& Jones, 1993). In cases where these relationships have not developed in Ontario's nursing programs, some college-university collaborations may, as a result, ultimately be unsuccessful. As Lang (2003) suggested in his discussion of merger in post-secondary education, inter-institutional collaborations are sometimes unsuccessful for the same reason that some marriages end in divorce: the partners are incompatible and their differences cannot be reconciled. He wisely points out that "partners should not be selected only because they are willing, available, and geographically nearby ... convenience and politically useful results should not form the basis of peer selection or the selection of partners" (p.32).

\section{Program Funding}

It should come as no surprise that government funding processes and incentives have been shown to have a significant influence on approaches to and the success of arrangements for inter-institutional collaboration (Gaber, 2003; Renaud, 2000; Skolnik, 1994). In designing the mechanism for funding the collaborative nursing programs in Ontario, the Ministry of Training, Colleges and Universities opted to flow the entire operating funding amount to the college engaged in the partnership rather than providing annual program operating funding directly to each college and each university delivering the collaborative nursing programs. In cases where partnerships involved more than one college, institutions are required to designate a college to be the recipient of operating grant funding. The Ministry's expectation is that these operating funds will be distributed amongst institutions in accordance with the partners' agreed terms.

Since authority to confer the nursing degree rests exclusively with the university partner, some policy makers felt that flowing all of the operating funding for collaboration through colleges would provide for a more level playing field. Considering the importance of respect for institutional autonomy in collaboration, the chosen funding process for collaborative nursing programs has the potential to contribute to a level of discord between colleges and universities. As Molzahan and Purkis (2004) have noted, explicit agreements on funding and resource sharing are especially important to the success of inter-institutional co-operation. In cases where collaborative partnerships do not have such agreements, additional administrative resources would be required to facilitate the apportionment of Ministry funding and the timing of the transfer of funds from the college partner receiving the operating grant. If this process enables a college to diminish the autonomy of its university partner, this process may have the potential to impact positive working relations.

There is also a question of whether the per-student amount of funding provided for the collaborative nursing program, which is the same level of funding provided for a baccalaureate student in a non-collaborative program, is sufficient to ensure the collaborative program's financial viability. Some of the additional costs of collaborative programs are associated with travel between delivery sites, joint meetings and conferences to co-ordinate program delivery, 
curriculum development, and undertaking joint marketing and admissions initiatives. It is entirely possible that the costs of delivering a high-quality collaborative program are significantly higher than the costs incurred in delivering a non-collaborative program.

\section{Implications for Faculty}

As Richardson (1993) has noted, there are often few incentives to encourage faculty to spend time on inter-sectoral activities. The role of college faculty is often narrowly defined in collective agreements or college-specific traditions. College faculty devote most of their time to teaching and student contact that is associated with classroom instruction. In contrast, university faculty spend fewer hours in the classroom but face significant time pressures due to the multiple demands to teach and advise graduate students, keep up demanding scholarly commitments to academic research and peer-review publications, and perform service to their institution - all within the competitive structure of university tenure and promotion systems.

The time commitment required to maintain effective collaborative nursing programs has important implications for faculty delivering the programs. If allowances are not made in light of these pressures, the programs can compel university faculty to sacrifice scholarly research and publication obligations in favour of carrying out the administrative planning and co-ordination functions necessary to supporting collaborations. On the other hand, when appropriate levels of faculty and staff resources are made available, inter-sectoral collaboration can mutually enhance the quality of programs (Molzahan \& Purkis, 2004). For example, provided with adequate supports, university faculty may have an opportunity to mentor their college faculty colleagues in carrying out research and scholarly activities that have traditionally not fallen within the purview of community colleges (e.g., joint publication, conference presentations).

\section{Implications for Students}

To date, very little investigation has taken place to uncover answers to questions about the impact of Ontario's collaborative nursing program on the students enrolled in the programs. For example, how has the change in the nursing education environment impacted their educational experience, their potential to excel and their perception of their chosen profession? In a study of the experience of transfer students in one of the articulated collaborative nursing programs between a large urban Ontario university and three rural community colleges, Cameron (2005) found that students faced a great a deal of stress and difficulty in moving to university after two initial years at in college setting. Consistent with findings of similar studies of transfer students, this would indicate that particular attention should be paid to the supports required by students in collaborative programs following the articulated model (Davies \& Dickman, 1998; Laanan, 1996; Townsend, 1995). But clearly, additional ex- 
amination of student experiences with the collaborative baccalaureate model is necessary if we are to fully understand the impact of the entry-to-practice baccalaureate requirement and the subsequent "reorganization" of nursing education at the baccalaureate level.

\section{Concluding Comments}

With the baccalaureate requirement for entry-to-practice to nursing firmly established and Ministry policies designed to favour collaborative programs, Ontario colleges and universities have few alternatives to the current collaborative baccalaureate model. In instances where collaborations are unsuccessful or in the event that there is a need to expand the current nursing education capacity in Ontario, government may consider two options: facilitating the expansion of university stand-alone nursing programs and supporting the development of college applied degree programs in nursing. Both of these options have limitations.

Currently, the Ministry of Training, College and Universities does not provide operating funding to Ontario universities for enrolment growth in standalone undergraduate nursing programs. Programs delivered without collaboration with a college are not eligible for funding beyond levels that existed prior to the implementation of the collaborative nursing program policies in 2000. This policy would need to change in the event that the expansion of university stand-alone nursing programs is at some point desired since, within the Ministry's current tuition fee framework, institutions are unlikely to expand student spaces without operating support. On the surface, this approach may not seem consistent with one of government's primary rationales for supporting the introduction of collaborative programs - maximizing the system-wide capacity and resources of pre-existing college and university programs. However, if maximum utilization of the post-secondary system's capacity to provide nursing education is the ultimate objective, it would seem contradictory to limit the expansion of enrolment in university stand-alone programs by restricting funding for nursing program enrolment growth to only those programs following a collaborative model. In light of the Ontario government's financial, and to a lesser degree, political investment in the college-university collaborative nursing model, at present it is unclear whether provincial policies may be modified to permit the expansion of university stand-alone programs.

When the Nursing Act was amended in 1999 to legislate the baccalaureate entry-to-practice requirement, government had not yet introduced the Postsecondary Choice and Excellence Act - giving legislative authority to CAATs to confer degrees in applied areas of study. Some in Ontario's post-secondary education community have advocated that colleges be permitted to offer applied degrees in nursing as an alternative to participation in the collaborative nursing program. In addition to ministerial consent, this would require the consent of the CNO and a change to the current registration regulations under the provincial Nursing Act. As more college applied degrees are introduced in the 
coming years and colleges gain experience delivering nursing degree programs in conjunction with university partners, the nursing community in Ontario may become receptive to the CAAT applied degree in nursing as an equivalent entry-to-practice education requirement for registered nurses. This has occurred in British Columbia (Molzahan \& Purkis, 1994). In the Ontario context, it is debatable whether college applied degrees would sufficiently meet the original program goals of the proponents of the baccalaureate entry-to-practice requirement. These goals include the integration of scholarly research activities in registered nurse education programs. Compared to universities, Ontario's community colleges have to date played only a relatively minor role in scholarly research. Questions have also arisen regarding the equivalency of college applied degrees for the purposes of entry to university graduate degree programs and second-entry professional degree programs (Marshall, 2006; Skolnik, 2005). Considering this, it is questionable whether, in the current circumstance, an applied degree in nursing would be a viable alternative to the college-university collaborative model.

At the time of this writing, the Ontario College-University Consortium Council is finalizing a large-scale evaluation of the collaborative baccalaureate in nursing to examine best practices and any barriers that have been encountered in establishing and maintaining effective delivery of the program. It is anticipated that, based on its findings, the CUCC will make recommendations for future directions to the Ontario government and to the college and university partners offering the program. In light of the fact that this program has been the most large-scale exercise in inter-sectoral collaboration in the province's history, the reaction of institutions and government to any recommendations will be of vital importance to not only the collaborative baccalaureate, but the future of this type of activity in Ontario's post-secondary system.

\section{REFERENCES}

Barton, L. (2005). On the cutting edge: Rethinking governance in interinstitutional co-operation arrangements in higher education. College Quarterly, 8(1), 8-28.

Cameron, C. (2005). Experiences of transfer students in a collaborative baccalaureate nursing program. Community College Review, 33(2), 22-44.

Canadian Association of Schools of Nursing. (2004). CASN definition of scholarship position statement. Ottawa, ON: Author.

Canadian Nurses Association. (1982). Entry to the practice of nursing: A background paper. Ottawa, ON: Author.

College-University Consortium Council. (1999). The Ontario college university degree-completion accord. Port Hope, ON: Author.

College-University Consortium Council. (2006). CUCC Mission statement. Retrieved July 12, 2006, from: http://cucc.cou.on.ca. 
Davies, T. G., \& Dickmann, E. M. (1998). Student voice in the transfer process: Do we hear them? Do we listen? Community College Journal of Research and Practice, 22, 541-557.

Dennison, J. D. (1995). Challenge and opportunity: Canada's community colleges at the crossroads. Vancouver, BC: University of British Columbia Press.

Dennison, J. D., \& Gallagher, P. (1986). Canada's community colleges. Vancouver, BC: University of British Columbia.

Gaber, D. A. (2003). Building a system of autonomous institutions: Coordinaton and collaboration in British Columbia's community college, university college and institute system. Community College Review, 31(2), 47-72.

Jones, G.A. (1997). Higher education in Ontario. In G.A. Jones (Ed.), Higher education in Canada: Different systems, different perspectives (pp. 137-159). New York: Garland.

Jones, G. A. (2004). Ontario higher education reform, 1995-2003: From modest modifications to policy reform. Canadian Journal of Higher Education, 34(3), pp. 39-54.

Kerr, J., \& MacPhail, J. (1996). Concepts in Canadian nursing. Toronto, ON: Mosby Inc.

Laanan, F. S. (1996). Making the transition: Understanding the adjustment process of community college transfer students. Community College Review, 23(4), 69-85.

Lang, D. W. (2003). The future of merger. What do we want mergers to do: Efficiency or diversity? Canadian Journal of Higher Education, 33(3), 19-46.

Marshall, D. (2006, May). Differentiation by degrees: Student mobility and the changing undergraduate environment in Canada. Paper presented at the Annual Conference of the Canadian Society for the Study of Higher Education, Toronto, ON.

Molzahan, A. E., \& Purkis, M. E. (2004). Collaborative nursing education programs: Challenges and issues. Nursing Leadership, 17(4), 41-53.

Nursing Education Implementation Committee. (1999). Report of the Nursing Education Implementation Committee. Toronto, ON: Author.

Ontario. (1990). Vision 2000: Quality and opportunity. Toronto, ON: Ministry of Colleges and Universities.

Ontario. (1993). No dead ends: Report of the Task Force on Advanced Training. Toronto, ON: Ministry of Education and Training.

Ontario. (1996). Excellence, accessibility, responsibility: Report of the Advisory Panel on Future Directions for Post-secondary Education. Toronto, ON: Ministry of Education and Training. 
Ontario. (1999). Good nursing, good health: An investment for the 21st Century. Report of the Nursing Task Force. Toronto, ON: Ministry of Health.

Ontario. (April 12, 2000). Collaborative nursing program guidelines. Toronto, ON: Ministry of Training, Colleges and Universities.

Ontario. (2001). Portals and pathways: Report of the Investing in Students Task Force. Toronto, ON: Ministry of Training, Colleges and Universities.

Ontario. (2005). Ontario: A leader in learning. Report and recommendations of the Post-secondary Review. Toronto, ON: Ministry of Training, Colleges and Universities.

Ontario. (2006). Nursing data for public disclosure. Toronto, ON: Ministry of Training, Colleges and Universities.

Provincial Steering Committee on the Future of Nursing Education. (1995). Education of the Nurse of the Future. Position Statement by the Provincial Steering Committee of the Colleges of Applied Arts and Technology Nursing Programs and the Council of Ontario University Programs in Nursing. Toronto, ON: Author.

Renaud, D. (2000). Exploring the barriers to articulation agreements between Ontario colleges and universities. Unpublished doctoral dissertation, University of Toronto.

Richardson, R. C. (1993). Faculty in the transfer and articulation process: Silent partners or missing link? Community College Review, 21(1), 41-47.

Skolnik, M.L. (1987). State control of degree granting: The establishment of a public monopoly in Canada. In C. Watson (Ed.), Governments and higher education: The legitimacy of intervention (pp. 56-83). Toronto, ON: Higher Education Group, Ontario Institute for Studies in Education.

Skolnik, M. L. (1994). Toward the creation of a CAAT-university partnership for an integrated baccalaureate program in nursing. College Quarterly, 1(3), 15-20.

Skolnik, M.L. (1995). Evolution of relations between community colleges and universities in Ontario. Community College Journal of Research and Practice, 19, 437-451.

Skolnik, M.L. (1996). Economic and financial considerations in the development of collaborative baccalaureate programs in nursing in Ontario. Toronto, ON: Heads of Nursing, Colleges of Applied Arts and Technology and the Council of Ontario University Programs in Nursing.

Skolnik, M. L. (2005). The community college baccalaureate in Canada: Addressing accessibility and workforce needs. In D. L. Floyd, M. L. Skolnik, \& K. P. Walker (Eds.), The community college baccalaureate: Emerging trends and policy issues (pp. 49-72). Sterling, VA: Stylus Publishing. 
Skolnik, M. L., \& Jones, G. (1993) Arrangements for co-ordination between university and college sectors in Canadian provinces. Canadian Journal of Higher Education, 23 (2), 56-73.

Stokes, P. (1989). College transfer revisited: A working paper. Toronto, ON: Council of Regents.

Townsend, B. K. (1995). Community college transfer students: A case study of survival. Review of Higher Education, 18(2), 175-193.

\section{CONTACT INFORMATION}

Dale Kirby

Assistant Professor

Faculty of Education

G.A. Hickman Building

Memorial University of Newfoundland

St. John's, NL A1B 3X8

e-mail: dkirby@mun.ca

Dr. Dale Kirby is an Assistant Professor in the Faculty of Education at Memorial University of Newfoundland. He teaches in the Post-Secondary Studies program. His research interests include the transition to post-secondary education and the labour force, with a focus on factors influencing student persistence and success, as well as post-secondary education policy and program development. Kirby is a co-investigator on a Social Sciences and Humanities Research Council of Canada (SSHRC) Community-University Research Alliance (CURA) study of student transition to post-secondary education and the workforce. 